\title{
Uses and limits of the clinical laboratory in the COVID-19 pandemic: a didactic review
}

\author{
Fernando Antonio Glasner da Rocha Araujo ${ }^{1}$
}

1. Professor Associado, Departamento de Medicina Interna e Apoio ao Diagnóstico, Faculdade de Medicina da Bahia, Universidade Federal da Bahia, Salvador, BA, Brasil.

http://dx.doi.org/10.1590/1806-9282.66.12.1718

\section{SUMMARY}

The world is currently experiencing an unprecedented pandemic of a new disease, the coronavirus disease (COVID-19), which has unusual clinical and immunological presentations. This is especially true regarding the choice and interpretation of laboratory test results. In this review, we have provided didactic information for physicians on the current concepts and practical guidance regarding COVID-19.

KEYWORDS: Severe acute respiratory syndrome - coronavirus 2, COVID-19, clinical pathology, clinical diagnosis, laboratory.

\section{INTRODUCTION}

The Coronavirus disease (COVID-19) is an infectious disease caused by severe acute respiratory syndrome coronavirus 2 (SARS-CoV-2). SARS-CoV-2 was first identified after an outbreak of pneumonia of unknown etiology in Wuhan, Hubei Province, China in December 2019. ${ }^{1}$

Laboratory tests can play different and important roles in medical decision making during the current COVID-19 pandemic by providing the following:

- Etiological diagnosis of the disease

- Serological diagnosis of the disease

- Immunological status evaluation

- Severity and/or prognosis indicators

The choice of test depends on the inherent characteristics of the test (sensitivity, specificity, and predictive values), the characteristics of the target population (prevalence, incidence, and pre- and posttest probability), and a combination of both (likelihood ratio).

Since COVID-19 is a novel disease, the current knowledge regarding its characteristics, especially laboratory characteristics, is limited. In this review, we have provided didactic information on the current concepts and practical guidance regarding COVID-19 based on the current knowledge to help physicians choose laboratory tests and interpret their results based on different clinical presentations.

\section{METHODS}

A literature review was performed to identify studies that met the objective of the research. The following strategies were used. First, a literature search was performed in PubMed and SciELO using the terms SARS-CoV-2, COVID-19, laboratory, and interpretation. Second, an active Google database search was performed using the specific terms SARS-CoV-2, COVID-19, laboratory, interpretation, polymerase chain reaction, and serology. Third, websites of several national (such as Ministry of Health, Brasil and Scientific Societies of Clinical Pathology and Infectious Diseases) and international (such as 
CDC-USA) scientific and government entities were searched for recommendations or practice guidelines. Lastly, articles cited in the previously selected articles and strategies were explored. We searched for articles published in 2020 in English, Portuguese, or Spanish.

\section{RESULTS AND DISCUSSION}

Using the aforementioned search strategy, 107 articles were initially found in the databases and 6 on the websites. After excluding the articles that did not meet the study criteria and including 4 articles referenced in previously selected articles, 24 articles were finally analyzed (Figure 1).

\section{FIGURE 1}

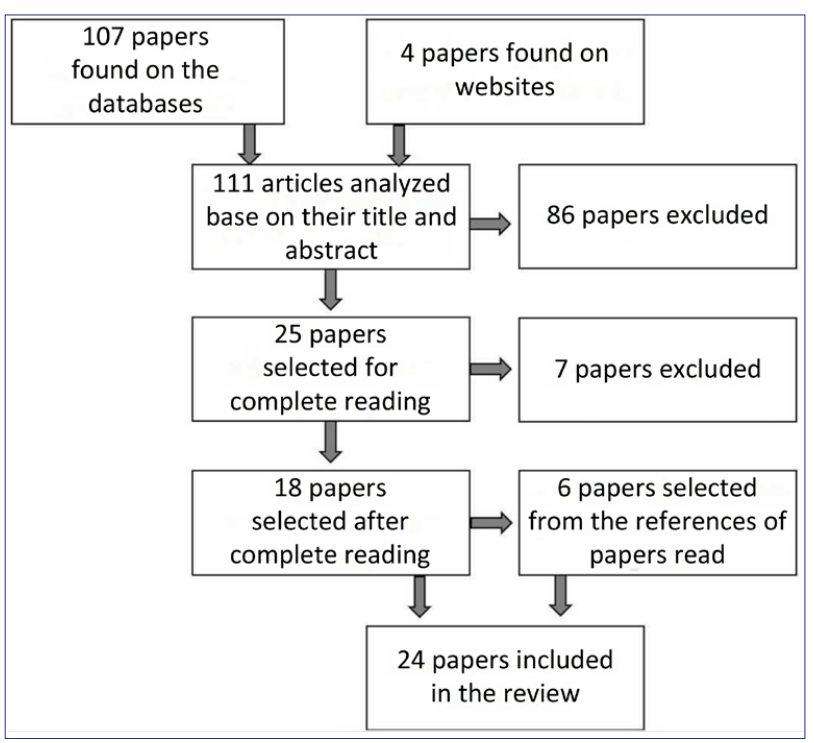

\section{Etiological diagnosis (molecular methods)}

The structure of SARS-CoV-2 (Figure 2) consists of a single RNA ribbon in the center surrounded by a nucleocapsid (N). This structure is wrapped in a lipid-membranous layer $(\mathrm{M})$ that has different proteins, such as envelope (E) and spiculated or spike (S) proteins, which gives the virus the appearance of thorns or tips of a crown (origin of the term corona). ${ }^{2}$ Molecular tests are based on the identification of the genes that encode these proteins using reverse transcription-polymerase chain reaction (RT-PCR). Currently, the genes used for identification are those coding for E, N, S, and RNA-dependent RNA polymerase. The tests usually identify more than one genetic marker, and most of them search for genes coding for $\mathrm{N}$ and $\mathrm{E}$.

\section{FIGURE 2}

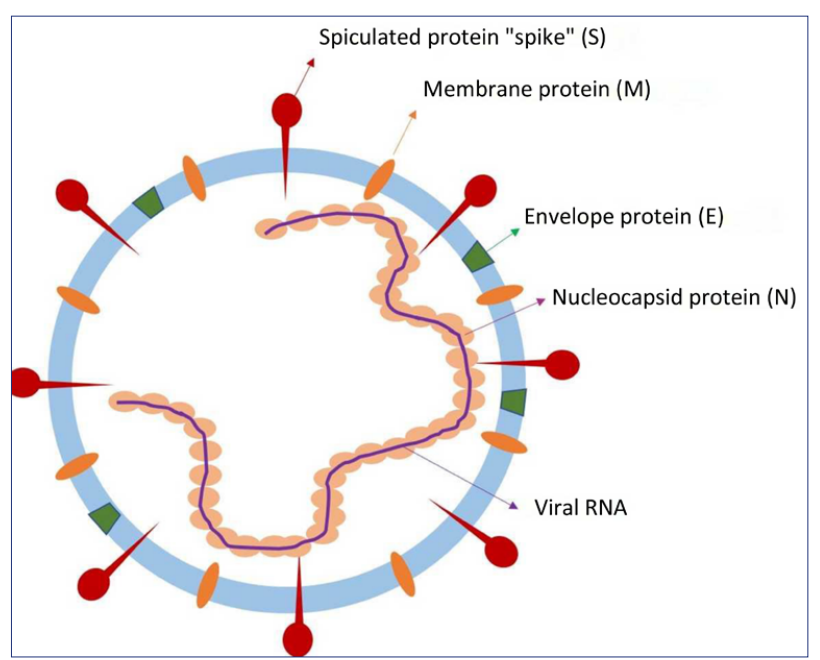

Reverse transcriptase-polymerase chain reaction

RT-PCR is the most widely used method for genetic identification of the virus and is considered the gold standard.

The ideal use of this test depends on factors such as the time and site of sample collection.

Kucirka et al. ${ }^{3}$ reported that the best time to collect samples for SARS-CoV-2 RT-PCR is between the third and fourth days after symptom onset (Table 1). Further, they reported that all patients tested in their pre-symptomatic phase were negative; therefore, testing asymptomatic patients would not be justified. However, Sakurai et al. ${ }^{4}$ observed that during the COVID-19 outbreak on the Diamond Princess ship, 712 of the 3,711 people aboard tested positive for COVID-19. Moreover, 410 of $712(58 \%)$ people were asymptomatic at the time of sample collection. These two reports, although containing contradictory findings, represent two distinct pre-test conditions. The first includes patients who, with no history of suspicious contact, wish to undergo the RT-PCR test to know if they were infected. The second includes an important precedent of prior contact. Therefore, only the latter scenario would justify the testing of asymptomatic individuals, considering that about half of them would test negative. The duration from the initial test to symptom onset was a mean of 4 days (range, $3-7$ days). ${ }^{4}$

Furthermore, only 8 of 32 (25\%) people on the Diamond Press ship who were cabin companions of COVID-19-positive patients subsequently tested positive. ${ }^{4}$ This justifies the frequent observation of different results among family members or people sharing the same household with COVID-19-infected persons. 
Almost all published studies are based on the collection of nasopharyngeal samples, wherein the sensitivity varies between $78 \%$ (for 1 test) and $86 \%$ (for 2 tests), with a specificity of about $99 \%$. Some authors have highlighted the increase in sensitivity for COVID19 diagnosis when RT-PCR is used in combination with chest computed tomography (sensitivity of $91.9 \%)^{5}$

A positive RT-PCR test probably means the actual presence of viral infection (true positivity), since false-positive results are very rare. False-positive results are most likely due to a processing error with the contamination of the tested sample. Test results that are not false-positive effectively identify viral genetic materials; however, it is necessary to consider the possibility of the occurrence of these materials even in the absence of viral replication, since the virus could be in an inactive state. ${ }^{6}$

The main limitation of this examination is the significant number of false-negative results because of diverse reasons such as:

- The viral load in secretions and excretions depends on the stage of infection; it is lower in samples collected less than 3 and more than 10 days after the onset of infection (Table 1). ${ }^{3}$

- The classical collection sites (nose and oropharynx) tend to show less positive tests than those collected in the lower respiratory tract (such as bronchoalveolar lavage); however, the collection technique of the latter is more complex and not available in most laboratories (Table 2). ${ }^{7}$

- Degradation of the sample during transportation and storage before analysis.

Many studies have reported the detectable presence of viral particles in the saliva, blood, feces, and urine; however, there are no routine protocols for diagnosis using these viral particles. ${ }^{8}$ Viral particle detection in the urine is very rare. ${ }^{9}$

A possible explanation for the difference in positivity between these different samples is the time taken to express viral replication. Most of the current knowledge comes from RT-PCR test results from the analysis of samples collected from the nasopharynx. Wölfel et al. ${ }^{10}$ described that sputum samples show positivity even after the virus is no longer detected in nasopharynx samples on RT-PCR. Zhang et al. ${ }^{9}$ demonstrated that the RT-PCR test results for fecal samples remain positive for a longer period than those for nasopharyngeal samples.

The reason why viral material tarries for more than 14 days in some samples and its relationship with the possibility of disease transmission is unclear.

Generally, since the occurrence of false-positive results is very rare, a positive RT-PCR test result can be considered a case of SARS-CoV-2 contamination. However, when analyzing a strongly suspected COVID-19 case (high pre-test probability) that presents a negative RT-PCR test result, it is recommended to repeat the test at least once, and if possible, it is recommended to collect the sample from the lower respiratory tract. ${ }^{1,11}$ Even if the results are negative, considering the high pre-test probability, it is better to isolate the patient. ${ }^{11}$

Watson et al. ${ }^{11}$ calculated pre-test and post-test probabilities using the sensitivity (70\%) and specificity (95\%) data for RT-PCR in the literature (Table 3).

TABLE 1. PREVALENCE OF FALSE-NEGATIVE RT-PCR TEST RESULTS FOR SARS-COV-2 BASED ON THE TIME OF SYMPTOM ONSET

\begin{tabular}{l|l} 
Time & False-negative results \\
\hline 4 days prior to symptom onset & $100 \%$ \\
\hline 1 day after symptom onset & $67 \%$ \\
\hline 3 days after symptom onset & $20 \%$ \\
\hline 4 days after symptom onset & $21 \%$ \\
\hline 16 days after symptom onset & $66 \%$ \\
\hline
\end{tabular}

Kucirka et al., $2020^{3}$

TABLE 2. SENSITIVITY BY COLLECTION SITE IN SARSCOV-2 CARRIERS

\begin{tabular}{l|l} 
Collection site & Sensitivity \\
\hline Bronchoalveolar lavage & $93 \%$ \\
\hline Sputum & $72 \%$ \\
\hline Nasopharynx & $63 \%$ \\
\hline Oropharynx & $32 \%$ \\
\hline
\end{tabular}

Wang et al., $2020^{7}$

TABLE 3. POST-TEST PROBABILITY OF POSITIVE AND NEGATIVE RT-PCR RESULTS

\begin{tabular}{l|l|l|l}
$\begin{array}{l}\text { Pre-test } \\
\text { probability }\end{array}$ & $\begin{array}{l}\text { Post-test } \\
\text { probability of } \\
1 \text { negative } \\
\text { result }\end{array}$ & $\begin{array}{l}\text { Post-test } \\
\text { probability of } \\
2 \text { negative } \\
\text { results }\end{array}$ & $\begin{array}{l}\text { Post-test } \\
\text { probability of } \\
1 \text { positive } \\
\text { result }\end{array}$ \\
\hline $5 \%$ & $1.6 \%$ & $0.5 \%$ & $42 \%$ \\
\hline $15 \%$ & $5 \%$ & $2 \%$ & $71 \%$ \\
\hline $25 \%$ & $10 \%$ & $3 \%$ & $82 \%$ \\
\hline $50 \%$ & $24 \%$ & $9 \%$ & $93 \%$ \\
\hline $75 \%$ & $49 \%$ & $23 \%$ & $98 \%$ \\
\hline $90 \%$ & $74 \%$ & $47 \%$ & $99 \%$ \\
\hline
\end{tabular}

Watson et al., 202011 
Reverse transcriptase loop-mediated isothermal amplification polymerase chain reaction

Although less common than RT-PCR, the RT loop-mediated isothermal amplification PCR (LAMP) technique has some advantages such as faster execution time, simpler reading (visual), the possibility of measurement at the point of care, and the possibility of running more tests simultaneously. ${ }^{12}$ Moreover, it presents a high specificity for SARS-CoV-2, and no cross-reaction with other coronaviruses (such as HCoV-229E, HCoV-NL63, HCoV-OC43, and MERS-CoV), influenza viruses (such as type B, H1N1pdm, H3N2, H5N1, H5N6, H5N8, and H7N9), or other respiratory viruses (such as RSVA, RSVB, ADV, PIV, MPV, and HRV). ${ }^{13}$

However, this technique needs higher viral loads, which reduces its detection limit, and is qualitative. ${ }^{6}$

At first, this would be the technique of choice for population use.

\section{Serological diagnosis}

Serological tests are based on the detection of antibodies produced against viral antigens. These tests can detect total or specific antibodies (IgM, IgG, and less commonly, IgA).

Antibody detection depends on the time elapsed since infection onset. IgA and IgM antibodies are usually detectable in the first 7 to 10 days of infection, whereas IgG can be detectable after about 10 to 15 days of infection. Ideally, these antibodies peak after the third or fourth week of illness. ${ }^{14}$

Patients whose clinical presentations are compatible with suspected COVID-19 and those with RT-PCR-confirmed COVID-19 present a positive antibody testing rate after 14 days of disease onset ranging from 50\% to $100 \%$ (mean $72 \%$ ) for IgM and $64.7 \%$ to $100 \%$ (mean 91\%) for IgG. In other words, even in patients positive for COVID-19 on RT-PCR, about 10\% do not present positive IgG; they constitute the so-called "false negatives" (Table 4). ${ }^{15}$

The reason why these patients present no seroconversion is unknown. These patients seem to show a similar tendency to that of those who develop no anti-HB antibodies even after repeated immunization attempts with a hepatitis B vaccine.

The percentage of positive antibody tests does not seem to depend on clinical severity. ${ }^{15}$

In addition to false-negative results, false-positive results can occur by cross-reaction with other viruses. This is more common when IgM or IgG titers are very close to the cutoff point. In the case of false-positive
TABLE 4. PERCENTAGE OF IGG SEROCONVERSION BASED ON THE TIME FROM INFECTION

\begin{tabular}{|c|c|c|c|c|}
\hline \multirow[t]{2}{*}{$1^{\text {st }}$ author } & \multirow[t]{2}{*}{ Technique } & \multicolumn{3}{|l|}{$\lg G$} \\
\hline & & Yes & No & $\%$ \\
\hline Gao & CLIA, ELISA, GICA & 14 & 0 & $100 \%$ \\
\hline Jiang & Proteome microarray & 29 & 0 & $100 \%$ \\
\hline Yong & GICA & 35 & 3 & $92 \%$ \\
\hline Liu & In-house kit & 131 & 2 & $98 \%$ \\
\hline Long & MCLIA & 285 & 0 & $100 \%$ \\
\hline Lou & ELISA, LFIA, CMIA & 75 & 5 & $94 \%$ \\
\hline Pan & ICG strip & 65 & 2 & $97 \%$ \\
\hline To & EIA & 16 & 0 & $100 \%$ \\
\hline Zhao & ELISA & 112 & 61 & $65 \%$ \\
\hline TOTAL & TOTAL & 762 & 73 & $91 \%$ \\
\hline
\end{tabular}

Flodgren et al., $2020^{15}$

results, it is recommended to repeat serum tests after 2 weeks. In the case of a true-positive reaction, a significant increase in IgG titers (double or more) is expected. In false-positive cases, IgG tends to be negative in the second sample analysis.

\section{Remote Laboratory Tests (rapid tests)}

Remote laboratory tests (RLTs) or point-of-care tests, also known as rapid tests, are performed outside the laboratory setting. They are aimed at rapidly screening for the presence of antibodies and do not require the expertise of trained personnel. Generally, they are based on immunochromatography techniques using whole blood on substrates assembled in molded plastic (soap type).

Their simple interpretation, easy technique, and rapid performance make them, at least theoretically, a very useful diagnostic tool (Figure 3). However, the performance characteristics reported by the manufacturers during validation are not standardized. Moreover, they do not provide information on the characteristics of the population tested. Many samples have presented inappropriately low-reliability data, resulting in tests with low accuracy and making their usefulness in clinical practice unfeasible. ${ }^{16}$

For these reasons, the World Health Organization recommends the use of RLTs for research purposes only, including public health surveys. Rapid tests are used to estimate disease seroprevalence in a given population. ${ }^{17}$

\section{Automated laboratory tests}

Automated laboratory tests are performed inside the laboratory using automated analytical equipment 
by trained personnel and ideally under the supervision of an experienced clinical pathologist. These tests are usually quantitative and have higher quality (accuracy, reproducibility, sensitivity, and specificity) than rapid tests.

Several methodologies have been used, but the most common are enzyme-linked immunosorbent assay (ELISA), chemiluminescence (CLIA), and electrochemiluminescence (ECL).

A comparison between these techniques shows that ECL is faster to implement, more sensitive, and more specific than the other automated techniques. ${ }^{18}$ However, the technique identifies total antibodies, without distinguishing between IgM or IgG classes.

ELISA and CLIA, although less sensitive, distinguish between antibody classes. Therefore, it would be ideal to initially use ECL, and in positive cases, perform the ELISA or CLIA.

\section{Immunological status evaluation}

Typically, the presence of antibodies is interpreted as follows. IgM: These are usually interpreted as indicators of the initial phase of the immune response and, therefore, of recent infection. However, with the introduction of increasingly sensitive tests, it has become common to detect IgM antibodies weeks and even months after infection. It is also necessary to consider that antibodies of this class are less specific than IgG. Therefore, IgM positivity may be related to a cross-reaction with antigens of other viruses. IgG: These are usually interpreted as indicators of patient immunization; however, with COVID-19, this interpretation has been questioned. In addition to the large number of patients who are not IgG positive, it has been described that infected asymptomatic patients produce less-lasting antibodies. ${ }^{19}$ The implications of these findings regarding the nature or duration of immunity and the efficacy of response to new viral attacks in the future is unclear.

A possible explanation for differences between IgG positivity and immune status, in Covid-19, is the type of target antigenic determinant the antibodies produced. Sethuraman et al. ${ }^{14}$ stated that most antibodies produced (and detected in assays) are directed toward the most abundant viral protein-the $\mathrm{N}$ protein. Thus, tests detecting the $\mathrm{N}$ protein are more sensitive; nonetheless, these are possibly not neutralizing antibodies and they may not indicate immunity. Conversely, antibodies directed toward the receptor-binding domain of the $\mathrm{S}$ protein are more specific and possibly neutralizing.

Atypical behaviors of anti-SARS-CoV-2 antibodies have been reported by Brazilian clinical pathologists ${ }^{20}$ :

- IgM antibodies tarry for more than 7 weeks, with no set time for negativity

- False-negative or indeterminate IgG results up to 50 days after the symptom onset with RT-PCR positivity

- IgG results that become positive 20 days after symptom onset, with slow growth and no prediction of reaching the IgG concentration plateau

- Some patients present no IgM positivity even in the active phase of infection

In addition to the clinical diagnosis of recent infection (IgM positivity) or immunization (IgG positivity) commonly used by doctors to follow-up cases, the Brazilian Society of Clinical Pathology/Laboratory Medicine ${ }^{21}$ highlights the following situations wherein these tests may be useful:

\section{FIGURE 3}

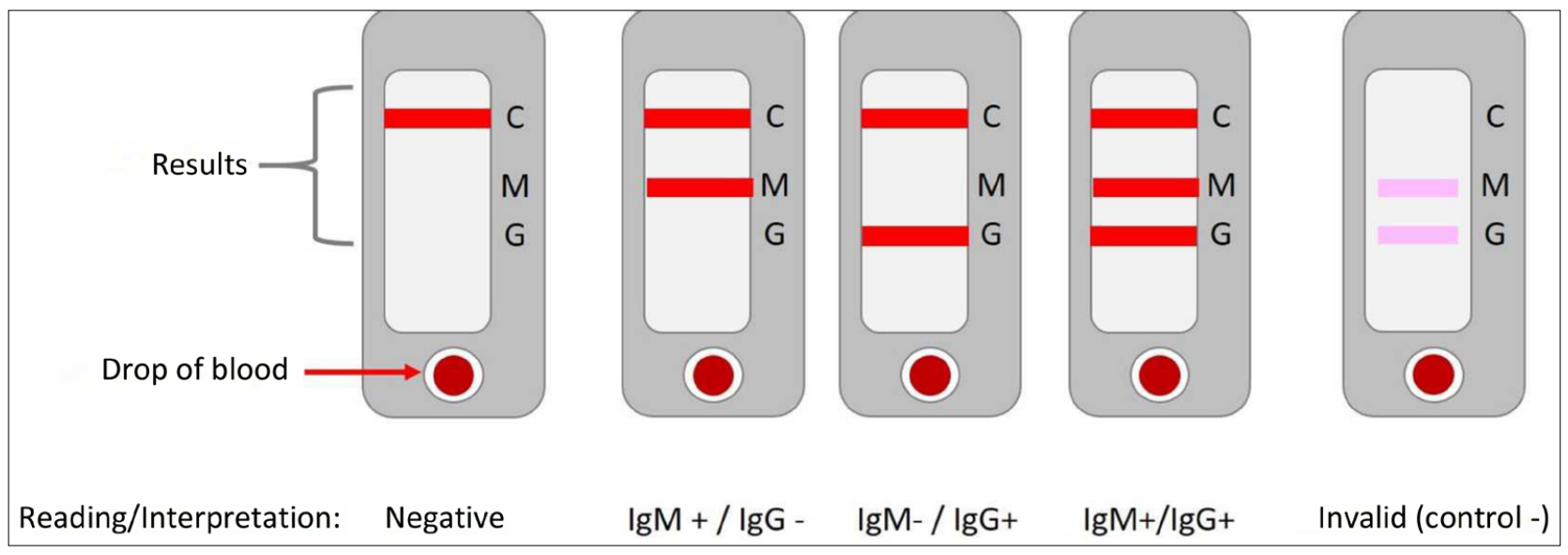


- The diagnosis of hospitalized patients with late clinical presentation (after the seventh day of symptom onset) as the first option before the PCR reaction. However, a negative result in this context does not rule out the diagnosis of COVID19 and specific molecular testing (RT-PCR) is recommended.

- Return to work evaluation for health professionals from the seventh day of symptom onset. As previously stated, a negative result does not exclude the diagnosis of COVID-19 and RT-PCR is recommended.

\section{Severity and/or prognosis indicators}

Ruan et al. described mortality predictors in 150 patients with COVID-19. Some of the clinical predictors were mean age ( $67 \mathrm{vs.} 50$ years), presence of comorbidities (especially cardiovascular disease, renal failure, respiratory failure, and associated infections), and disease severity (need for ICU admission and life support). The laboratory parameters associated with a fatal outcome described were leukocytosis $(10,620$ vs. $6,760 / \mathrm{mm}^{3}$ ), lymphopenia (600 vs. $1,420 / \mathrm{mm}^{3}$ ), thrombopenia $\left(173,600 \mathrm{vs}, 222,100 / \mathrm{mm}^{3}\right)$, evidence of renal failure (increased blood urea nitrogen and serum creatinine levels), changes in muscle enzyme levels (myoglobin and cardiac troponin levels), and changes in inflammatory response markers (decreased albumin levels and increased C-reactive protein, ferritin, and IL-6 levels). ${ }^{22}$

Coagulopathy is a recognized risk factor for COVID19 mortality and expressed by significantly increased levels of D-dimer and fibrin degradation products. ${ }^{23}$

\section{CONCLUSION}

Table 5 shows the different clinical and epidemiological situations that physicians might encounter while treating patients with COVID-19 and the procedures that are most supported by current knowledge.

The beginning of the interpretation is based on the elapsed time since symptom onset.

In the absence of symptoms, the interpretation is based on the time elapsed since close contact with a SARS-CoV-2 carrier, evidenced by molecular testing. The more intimate and prolonged the contact, the more significant the history. However, the concept of close contact with a SARS-CoV-2 carrier can be quite broad, and includes the following ${ }^{24}$ :
TABLE 5. CHOICE OF TESTS IN DIFFERENT CLINICAL EPIDEMIOLOGICAL SITUATIONS

\begin{tabular}{|c|c|c|c|}
\hline $\begin{array}{l}\text { Patient clinical and } \\
\text { epidemiological }\end{array}$ & $\begin{array}{l}\text { Reason for } \\
\text { test }\end{array}$ & $\begin{array}{l}\text { First- } \\
\text { choice } \\
\text { test }\end{array}$ & $\begin{array}{l}\text { What to do } \\
\text { if the result } \\
\text { is negative }\end{array}$ \\
\hline \multirow[t]{2}{*}{$\begin{array}{l}\text { Asymptomatic with no } \\
\text { history of contact with } \\
\text { carriers }\end{array}$} & $\begin{array}{l}\text { Find out if } \\
\text { the patient } \\
\text { has been } \\
\text { contaminated } \\
\text { before }\end{array}$ & $\begin{array}{l}\text { No indi- } \\
\text { cation for } \\
\text { testing }\end{array}$ & - \\
\hline & $\begin{array}{l}\text { Assess the } \\
\text { population } \\
\text { incidence of } \\
\text { virus infec- } \\
\text { tion/ } \\
\text { immunization }\end{array}$ & $\begin{array}{l}\text { RLT "Rap- } \\
\text { id Test" } \\
\text { (immuno- } \\
\text { chroma- } \\
\text { tography) }\end{array}$ & - \\
\hline $\begin{array}{l}\text { Asymptomatic after } \\
\text { contact with COVID-19 } \\
\text { patient }\end{array}$ & $\begin{array}{l}\text { Define } \\
\text { quarantine } \\
\text { requirement }\end{array}$ & RT-PCR & $\begin{array}{l}\text { Serology } \\
\text { after } 15-30 \\
\text { days of } \\
\text { contact }\end{array}$ \\
\hline $\begin{array}{l}\text { Patient with early } \\
\text { symptoms suggestive of } \\
\text { COVID-19 (up to } 7 \text { days } \\
\text { from symptom onset, } \\
\text { ideally between 3-4 days) }\end{array}$ & $\begin{array}{l}\text { Diagnosis of } \\
\text { the disease }\end{array}$ & RT-PCR & $\begin{array}{l}\text { Serology } \\
\text { (after } 15 \\
\text { days of } \\
\text { symptom } \\
\text { onset) }\end{array}$ \\
\hline $\begin{array}{l}\text { Patient with symptoms } \\
\text { suggestive of COVID-19 } \\
\text { with late symptom onset } \\
\text { (after day } 7 \text { and before } 14 \\
\text { days of symptoms) }\end{array}$ & $\begin{array}{l}\text { Diagnosis of } \\
\text { the disease }\end{array}$ & $\begin{array}{l}\text { RT-PCR + } \\
\text { chest CT }\end{array}$ & $\begin{array}{l}\text { Serology } \\
\text { (after } 15 \\
\text { days of } \\
\text { symptom } \\
\text { onset) }\end{array}$ \\
\hline $\begin{array}{l}\text { Symptomatic or recovered } \\
\text { patient, more than } 15 \text { days } \\
\text { after symptom onset }\end{array}$ & & Serology & \\
\hline $\begin{array}{l}\text { The patient recovered } \\
\text { from COVID-19, after } 7 \\
\text { days }\end{array}$ & $\begin{array}{l}\text { Evaluate } \\
\text { return to work } \\
\text { of health } \\
\text { personnel }\end{array}$ & RT-PCR & Serology \\
\hline $\begin{array}{l}\text { Patient recovered from } \\
\text { COVID-19, more than } 14 \\
\text { days after the first symp- } \\
\text { tom onset }\end{array}$ & $\begin{array}{l}\text { Diagnosis } \\
\text { (retrospec- } \\
\text { tive) of the } \\
\text { disease }\end{array}$ & Serology & \\
\hline
\end{tabular}

- A person who had direct physical contact (e.g., shaking hands).

- A person who had unprotected direct contact with infectious secretions (e.g., cough droplets, unprotected contact with used tissue or tissues containing secretions).

- A person who had face-to-face contact for at least $15 \mathrm{~min}$ and at a distance of at least 2 m apart.

- A person who was in an enclosed environment (e.g., classroom, meeting room, hospital waiting room, etc.) for at least $15 \mathrm{~min}$ and at a distance of at least $2 \mathrm{~m}$ apart.

- A health care professional or another person directly handling a COVID-19 case or laboratory workers handling samples from a COVID-19 case without recommended personal protective equipment (PPE) or with a possible PPE violation. 
- An aircraft passenger seated within a radius of two seats (in either direction) from a confirmed case of COVID-19, his companions, or caregivers, and the crew members who worked in the aircraft section where the patient was seated.

- A person who lives in the same house/environment. Residents of the same house, dormitory, nursery, and accommodation should be considered.

Finally, we hope that this text will be useful and contribute to the better use of the laboratory in the diagnosis of SARS-Cov-2. Much of the knowledge about this condition will continue to evolve in the coming months, adding or changing part of what we have reviewed today.

PALAVRAS-CHAVE: síndrome respiratória aguda grave - coronavírus 2, COVID-19, patologia clínica, diagnóstico clínico, laboratório.

\section{REFERENCES}

1. Ministerio da Saude. Protocolo de Manejo Clínico do Coronavírus (COVID19) na Atenção Primária à Saúde. (Ministerio da Saúde, 2020).

2. Li, G. et al. Coronavirus infections and immune responses. J. Med. Virol. 92, 424-432 (2020)

3. Kucirka, L. M., Lauer, S. A., Laeyendecker, O., Boon, D. \& Lessler, |. Variation in False-Negative Rate of Reverse Transcriptase Polymerase Chain Reaction-Based SARS-CoV-2 Tests by Time Since Exposure. Ann. Intern. Med. M20-1495 (2020). doi:10.7326/M20-1495

4. Sakurai, A. et al. Natural History of Asymptomatic SARS-CoV-2 Infection. N. Engl. J. Med. NEJMc2013020 (2020). doi:10.1056/NEJMc2013020

5. Jiang, G. et al. Application and optimization of RT-PCR in diagnosis of SARS-CoV-2 infection. medRxiv 2020.02.25.20027755 (2020). doi:10.1101/2020.02.25.20027755

6. Motley, M. P., Bennett-Guerrero, E., Fries, B. C. \& Spitzer, E. D. Review of Viral Testing (Polymerase Chain Reaction) and Antibody/Serology Testing for Severe Acute Respiratory Syndrome-Coronavirus-2 for the Intensivist. Crit. Care Explor. 2, e0154 (2020)

7. Wang, W. et al. Detection of SARS-CoV-2 in Different Types of Clinical Specimens. JAMA (2020). doi:10.1001/jama.2020.3786

8. Vieira, L. M. F., Emery, E. \& Andriolo, A. COVID-19 - Diagnóstico laboratorial para os clínicos/COVID-19. (2020).

9. Zheng, S. et al. Viral load dynamics and disease severity in patients infected with SARS-CoV-2 in Zhejiang province, China, January-March 2020: retrospective cohort study. BMJ m1443 (2020). doi:10.1136/bmj.m1443

10. Wölfel, R. et al. Virological assessment of hospitalized patients with COVID2019. Nature 581, 465-469 (2020).

11. Watson, J., Whiting, P. F. \& Brush, J. E. Interpreting a COVID-19 test result. BMJ 369, m1808 (2020)

12. Yan, C. et al. Rapid and visual detection of 2019 novel coronavirus (SARS CoV-2) by a reverse transcription loop-mediated isothermal amplification assay. Clin. Microbiol. Infect. 26, 773-779 (2020).
13. Baek, Y. H. et al. Development of a reverse transcription-loop-mediated isothermal amplification as a rapid early-detection method for novel SARSCoV-2. Emerg. Microbes Infect. 9, 998-1007 (2020).

14. Sethuraman, N., Jeremiah, S. S. \& Ryo, A. Interpreting Diagnostic Tests for SARS-CoV-2. JAMA 323, 2249 (2020).

15. Flodgren, G. M. Immunity after SARS-CoV-2 infection. Rapid review. (2020).

16. Lisboa Bastos, M. et al. Diagnostic accuracy of serological tests for COVID19: systematic review and meta-analysis. BMJ m2516 (2020). doi:10.1136/ bmj.m2516

17. WHO. Advice on the use of point-of-care immunodiagnostic tests for COVID-19. WHO/2019-nCoV/Sci_Brief/POC_immunodiagnostics/2020.1 (2020). Available at: https://www.who.int/publications/i/item/advice-onthe-use-of-point-of-care-immunodiagnostic-tests-for-COVID-19-scientific-brief. (Accessed: 29th June 2020)

18. Lou, B. et al. Serology characteristics of SARS-CoV-2 infection since the exposure and post symptoms onset. medRxiv 2020.03.23.20041707 (2020). doi:10.1101/2020.03.23.20041707

19. Long, $Q$.-X. et al. Clinical and immunological assessment of asymptomatic SARS-CoV-2 infections. Nat. Med. (2020). doi:10.1038/s41591-020-0965-6

20. Dias, V. M. de C. H. et al. Testes Sorológicos para COVID-19: Interpretação e Aplicações Práticas. J. Infect. Control 9, (2020).

21. Sociedade Brasileira de Patologia Clínica / Medicina Laboratorial. Recomendações da SBPC/ML. Métodos Laboratoriais para Diagnóstico da Infecção pelo SARS-CoV-2. Revista Notícias Medicina Laboratorial 16-17 (2020).

22. Ruan, Q., Yang, K., Wang, W., liang, L. \& Song, I. Clinical predictors of mortality due to COVID-19 based on an analysis of data of 150 patients from Wuhan, China. Intensive Care Med. 46, 846-848 (2020).

23. Tang, N., Li, D., Wang, X. \& Sun, Z. Abnormal coagulation parameters are associated with poor prognosis in patients with novel coronavirus pneumonia. J. Thromb. Haemost. 18, 844-847 (2020)

24. Secretaria de Saude do Espirito Santos. Nota Técnica COVID-19 n 03/2020 Definições de Afastamento Laboral Para Profissionais de Serviços Essenciais. (2020). 